Technological University Dublin

DÜBLIN

ARROW@TU Dublin

2009-9

\title{
Copper(II) Complexes of Coumarin-Derived Schiff Bases and their anti-Candida Activity
}

\author{
Bernadette S. Creaven \\ Technological University Dublin \\ Michael Devereux \\ Technological University Dublin, Michael.Devereux@tudublin.ie \\ Dariusz Karcz \\ Technological University Dublin, dariusz.karcz@tudublin.ie
}

See next page for additional authors

Follow this and additional works at: https://arrow.tudublin.ie/ittsciart

Part of the Medicinal Chemistry and Pharmaceutics Commons, and the Pharmacology Commons

\section{Recommended Citation}

Creaven, B. et al. Copper(II) complexes of coumarin-derived Schiff bases and their anti-Candida activity. Journal of Inorganic Biochemistry, 103 (2009) 1196-1203. doi:10.1016/j.jinorgbio.2009.05.017

This Article is brought to you for free and open access by the School of Science and Computing at ARROW@TU Dublin. It has been accepted for inclusion in Articles by an authorized administrator of ARROW@TU Dublin. For more information, please contact

arrow.admin@tudublin.ie, aisling.coyne@tudublin.ie, gerard.connolly@tudublin.ie.

Funder: Technological Sector Research Programme, Strand 1, under the European Social Fund

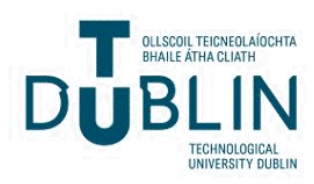




\section{Authors}

Bernadette S. Creaven, Michael Devereux, Dariusz Karcz, Andrew Kellett, Malachy McCann, Andy Noble, and Maureen Walsh

This article is available at ARROW@TU Dublin: https://arrow.tudublin.ie/ittsciart/30 
Provided for non-commercial research and education use. Not for reproduction, distribution or commercial use.

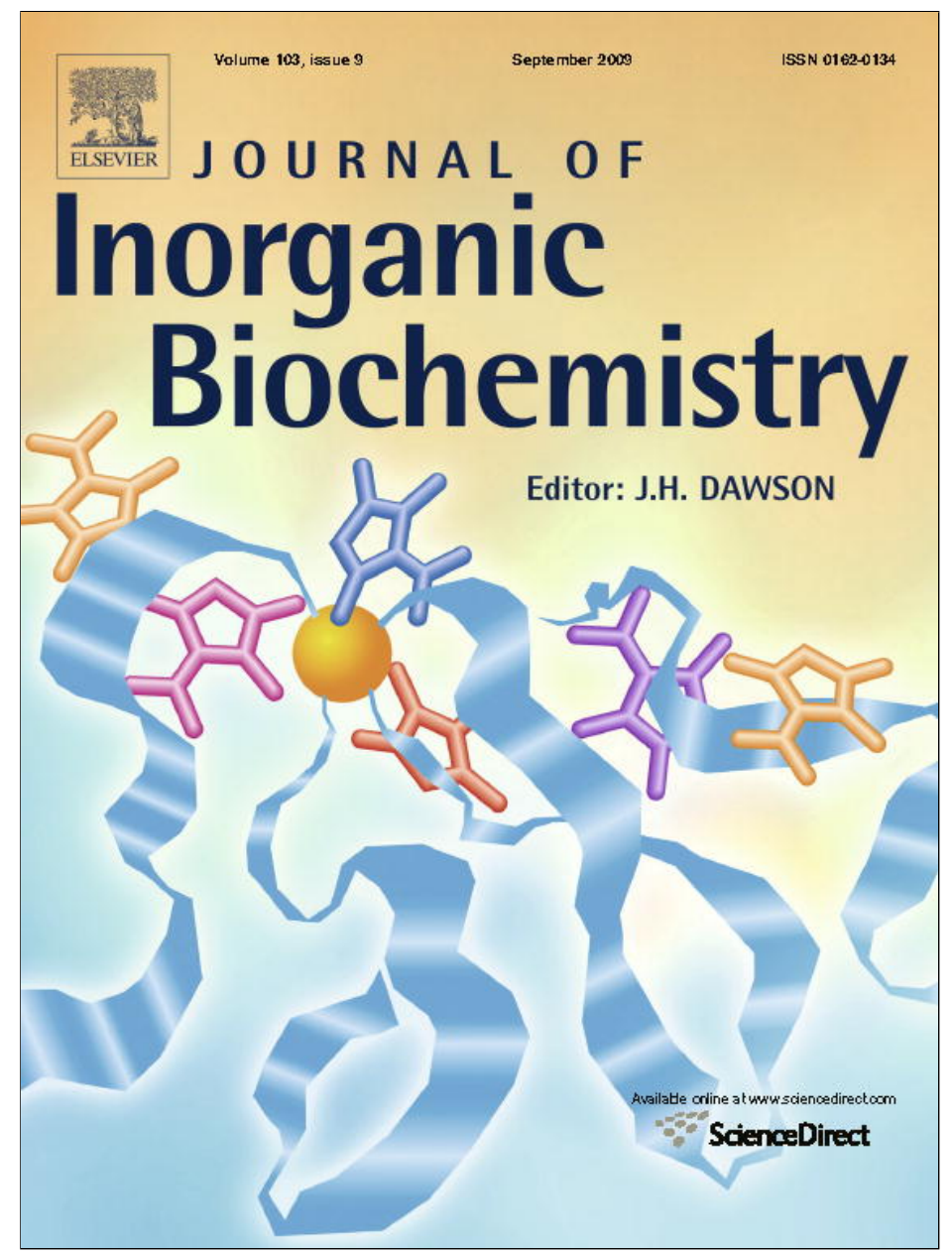

This article appeared in a journal published by Elsevier. The attached copy is furnished to the author for internal non-commercial research and education use, including for instruction at the authors institution and sharing with colleagues.

Other uses, including reproduction and distribution, or selling or licensing copies, or posting to personal, institutional or third party websites are prohibited.

In most cases authors are permitted to post their version of the article (e.g. in Word or Tex form) to their personal website or institutional repository. Authors requiring further information regarding Elsevier's archiving and manuscript policies are encouraged to visit:

http://www.elsevier.com/copyright 


\title{
Copper(II) complexes of coumarin-derived Schiff bases and their anti-Candida activity
}

\author{
Bernadette S. Creaven ${ }^{\mathrm{a}, \mathrm{b}, *}$, Michael Devereux ${ }^{\mathrm{c}}$, Dariusz $\operatorname{Karcz}^{\mathrm{a}, \mathrm{b}}$, Andrew Kellett ${ }^{\mathrm{c}}$, \\ Malachy McCann ${ }^{\mathrm{d}}$, Andy Noble ${ }^{\mathrm{e}}$, Maureen Walsh ${ }^{\mathrm{a}, \mathrm{b}}$ \\ ${ }^{a}$ Department of Science, Institute of Technology Tallaght, Dublin 24, Ireland \\ ${ }^{\mathrm{b}}$ Centre for Applied Science and Health, Institute of Technology Tallaght, Dublin 24, Ireland \\ ${ }^{\mathrm{c}}$ The Inorganic Pharmaceutical and Biomimetic Research Group, Focas Institute, Dublin Institute of Technology, Kevin St., Dublin 2, Ireland \\ ${ }^{\mathrm{d}}$ Department of Chemistry, National University of Ireland, Maynooth, Co. Kildare, Ireland \\ ${ }^{\mathrm{e}}$ Department of Chemistry, University of Otago, P.O. Box 56, Dunedin, New Zealand
}

\section{A R T I C L E I N F O}

\section{Article history:}

Received 6 February 2009

Received in revised form 19 May 2009

Accepted 22 May 2009

Available online 11 June 2009

\section{Keywords:}

Coumarin

Copper

Metal complexes

X-ray crystal structures

Antifungal

\begin{abstract}
A B S T R A C T
The condensation of 7-amino-4-methyl-coumarin (1) with a number of substituted salicylaldehydes yielded a series of Schiff bases (2a-2k) in good yields. Subsequent reaction of these ligands with copper(II) acetate yielded $\mathrm{Cu}(\mathrm{II})$ complexes (3a-3k) and some were characterised using X-ray crystallography. All of the free ligands and their metal complexes were tested for their anti-Candida activity. A number of the ligands and complexes exhibited anti-Candida activity comparable to that of the commercially available antifungal drugs, ketoconazole and Amphotericin B.
\end{abstract}

(C) 2009 Elsevier Inc. All rights reserved.

\section{Introduction}

Fungal pathogens represent the major eukaryotic agents of serious infection in European countries [1]. Infections due to Candida albicans and Aspergillus fumigatus are the most common and clinically important pathogens and indeed Candida now ranks as the fourth most common cause of nosocomial bloodstream infections [2]. In some cases, such as patients with malignant haematological disease and in bone-marrow transplant recipients, candidosis is the most common invasive fungal infection [3]. The development of azole-based antifungal drugs has considerably impacted on the fight against fungal infections, but the necessity to use high doses or combinations of drug therapies results in considerable side effects in patients and resistance to these drugs has also been reported [4-6]. Indeed, the repertoire of available antifungal chemotherapeutic agents is inadequate to treat life-threatening infections that are characterised by morbidities that exceed those due to the most important bacterial and viral diseases [7-13]. Therefore, there is an urgent need to generate new, efficacious, non-toxic compounds with broad-spectrum antifungal activity.

\footnotetext{
* Corresponding author. Address: Department of Science, Institute of Technology Tallaght, Dublin 24, Ireland. Tel.: +353 1 4042889; fax: +35314042700.

E-mail addresses: bernie.creaven@it-tallaght.ie, Bernie.creaven@ittdublin.ie (B.S Creaven).
}

Derivatives of coumarin are known to possess significant antifungal as well as antibacterial properties, and there are a number of commercially available coumarin-based antibiotics such as Novobiocin, Clorobiocin and Coumermycin $\mathrm{A}_{1}$. Many of the coumarins present in plants, and also their synthetic analogues, have been reported to be good antifungal and antibacterial agents [14-21]. Preliminary structure-activity relationship studies have shown that the presence of hydroxyl or carboxylic groups on the coumarin nucleus are necessary for antimicrobial activity [22]. We have previously published a number of studies on both carboxylate- and hydroxy-substituted coumarin ligands, and while the ligands themselves were not active against fungal species a number of their $\mathrm{Ag}(\mathrm{I})$ and $\mathrm{Cu}(\mathrm{II})$ complexes showed good antimicrobial activity [23-25]. Indeed, the silver carboxylate complexes showed excellent activity against MRSA but they were less promising antifungal agents [24]. A series of $\mathrm{Cu}$ (II) coumarin dioxyacetic acetate complexes displayed promising antibacterial activity but also showed reduced activity against fungal strains [25].

Schiff bases are a class of compound which is known to exhibit antifungal activity [26,27]. Schiff bases derived from 5-nitrosalicylaldehyde and amines, such 0 - and $p$-aminophenols, were prepared by Murthy et al. [28] and a number of metal complexes of the resulting ligands were tested for their antibacterial activity. Raman et al. have recently reviewed a series of transition metal complexes of Schiff bases derived from 4-aminoantipyrine and reported their 
antimicrobial activity [29]. These workers found that the complexes were active against bacterial strains but not particularly effective against $C$. albicans. Coumarin-derived Schiff bases are well known compounds and several reports have been written about their applications as dye and fluorescent agents [30,31]. Iminocoumarins have also been shown to exhibit anti-inflammatory, antibacterial and antifungal activities [32-35].

$\mathrm{Cu}$ (II) complexes of some organic drugs have been the subject of a number of studies aimed at establishing the presumed synergy between the $\mathrm{Cu}$ (II) ion and the drug [36-39]. In more recent years there have been numerous reports highlighting the significant biological activity of $\mathrm{Cu}$ (II) Schiff base complexes [40-46]. Patil et al. detailed the preparation of $\mathrm{Co}(\mathrm{II}), \mathrm{Ni}(\mathrm{II})$ and $\mathrm{Cu}(\mathrm{II})$ complexes with 1,2,4-triazole-derived coumarin Schiff bases and assessed their biological activity [47]. In this work, we have prepared a series of coumarin-derived Schiff bases and their $\mathrm{Cu}(\mathrm{II})$ complexes and the anti-Candida activity of the metal-free ligands and the complexes were assessed. Included, are the first crystal structures of $\mathrm{Cu}$ (II) Schiff-base coumarin complexes.

\section{Experimental}

\subsection{Materials/instrumentation}

All chemicals purchased from Sigma-Aldrich were reagent grade and used without purification. Infrared spectra were recorded in the region of $4000-400 \mathrm{~cm}^{-1}$, on a Nicolet Impact 410 Fourier-Transform Infrared spectrophotometer using Omnic software. Melting point values were measured using a Stuart scientific SMP1 melting point apparatus (up to $320^{\circ} \mathrm{C}$ ). ${ }^{1} \mathrm{H}$ NMR spectra were recorded in the region of -5 to $15 \mathrm{ppm}$ from TMS with a resolution of $0.0006 \mathrm{ppm} .{ }^{13} \mathrm{C}$ NMR spectra were recorded in the region -33 to $233 \mathrm{ppm}$ from tetramethyl silane (TMS) with a resolution of $0.008 \mathrm{ppm}$. All of the NMR spectra were run on a JEOL JNMLA300 FT-NMR (300 MHz ${ }^{1} \mathrm{H}$ and $75 \mathrm{MHz}{ }^{13} \mathrm{C}$ ) in $\mathrm{d}_{6}$-DMSO. Atomic absorption spectroscopy (AAS) measurements were taken on a Perkin-Elmer 460 AAS instrument (emission wavelength $324.8 \mathrm{~nm}$ ). UV-visible (UV-vis) spectra were recorded on a Hitachi U-2001 Spectrophotometer. Microanalytical data were provided by the Microanalytical Laboratory, National University of Ireland Dublin, Belfield, Dublin 4. Solid state magnetic susceptibility measurements were carried out at room temperature using a Johnson Matthey Magnetic Susceptibility Balance with $\mathrm{Hg}[\mathrm{Co}(\mathrm{SCN}) 4]$ being used as a reference standard.

\subsection{Synthesis of 7-amino-4-methylcoumarin (1)}

7-Amino-4-methyl-coumarin (1) was synthesised via a one step von Pechmann reaction using a modified literature procedure [48].

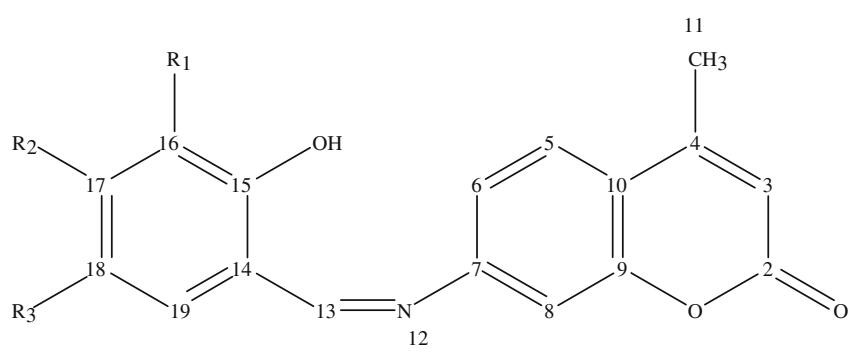

Fig. 1. Structure of the Schiff bases (2a-2k) showing the numbering system used in the assignment of ${ }^{\mathbf{1}} \mathrm{H}$ and ${ }^{\mathbf{1}} \mathrm{C}$ NMR spectra.
Table 1

Starting aldehyde and identification of functional groups on Schiff bases $\mathbf{2 a - 2 k}$.

\begin{tabular}{lllll}
\hline Starting aldehyde & $\begin{array}{l}\text { Schiff } \\
\text { base }\end{array}$ & $R_{1}$ & $R_{2}$ & $R_{3}$ \\
\hline 2-Hydroxybenzaldehyde & $\mathbf{2 a}$ & $-\mathrm{H}$ & $-\mathrm{H}$ & $-\mathrm{H}$ \\
2,3-Dihydroxybenzaldehyde & $\mathbf{2 b}$ & $-\mathrm{OH}$ & $-\mathrm{H}$ & $-\mathrm{H}$ \\
2,4-Dihydroxybenzaldehyde & $\mathbf{2 c}$ & $-\mathrm{H}$ & $-\mathrm{OH}$ & $-\mathrm{H}$ \\
2-Hydroxy-3-methoxybenzaldehyde & $\mathbf{2 d}$ & $-\mathrm{OCH}_{3}$ & $-\mathrm{H}$ & $-\mathrm{H}$ \\
2-Hydroxy-3-ethoxybenzaldehyde & $\mathbf{2 e}$ & $-\mathrm{OCH}_{2} \mathrm{CH}_{3}$ & $-\mathrm{H}$ & $-\mathrm{H}$ \\
2-Hydroxy-4-methoxybenzaldehyde & $\mathbf{2 f}$ & $-\mathrm{H}$ & $-\mathrm{OCH}$ & $-\mathrm{H}$ \\
3,5-Dichloro-2-hydroxybenzaldehyde & $\mathbf{2 g}$ & $-\mathrm{Cl}$ & $-\mathrm{H}$ & $-\mathrm{Cl}$ \\
3,5-Dibromo-2-hydroxybenzaldehyde & $\mathbf{2 h}$ & $-\mathrm{Br}$ & $-\mathrm{H}$ & $-\mathrm{Br}$ \\
3,5-Diiodo-2-hydroxybenzaldehyde & $\mathbf{2 i}$ & $-\mathrm{I}$ & $-\mathrm{H}$ & $-\mathrm{I}$ \\
2-Hydroxy-5-nitrobenzaldehyde & $\mathbf{2 j}$ & $-\mathrm{H}$ & $-\mathrm{H}$ & $-\mathrm{NO}_{2}$ \\
2-Hydroxy-3-methoxy-5- & $\mathbf{2 k}$ & $-\mathrm{OCH}$ & $-\mathrm{H}$ & $-\mathrm{NO}_{2}$ \\
nitrobenzaldehyde & & & & \\
\hline
\end{tabular}

\subsection{Synthesis of Schiff base ligands}

All of the Schiff bases 2a-2k (Fig. 1 and Table 1) were synthesised using the following general procedure. A solution of the appropriate aldehyde $(3 \mathrm{mmol})$ in ethanol $(10 \mathrm{~mL})$ was added slowly to a solution of $1(0.52 \mathrm{~g}, 3 \mathrm{mmol})$ in ethanol $(50 \mathrm{~mL})$ (see Table 2). Glacial acetic acid $(0.25 \mathrm{~mL})$ was then added and solution was heated under reflux for $2 \mathrm{~h}$. After cooling, the product was isolated by filtration, washed with cold methanol and allowed to dry in air. The Schiff bases $\mathbf{2 a - 2 g}$ were recrystallised from ethanol $(100 \mathrm{~mL})$. Assignments of NMR spectra of the ligands are based on the numbering scheme shown in Fig. 1 . Substituents $R_{1}, R_{2}$, and $R_{3}$ of the aldehyde moiety are given in Table 1 . All of the ligands were fully characterised by ${ }^{1} \mathrm{H},{ }^{13} \mathrm{C}$ NMR, IR, and UV-vis spectroscopies as well as by melting point and elemental analysis (Tables 3-6).

Table 2

Crystal data and structure refinement for the complexes $\mathbf{3 a}$ and $\mathbf{3 h}$.

\begin{tabular}{|c|c|c|}
\hline Complex & $3 a$ & $3 h$ \\
\hline Empirical formula & $\mathrm{C}_{68} \mathrm{H}_{48} \mathrm{Cu}_{2} \mathrm{~N}_{4} \mathrm{O}_{12}$ & $\mathrm{C}_{34} \mathrm{H}_{20} \mathrm{Br}_{4} \mathrm{CuN}_{2} \mathrm{O}_{6}$ \\
\hline Formula weight & 1240.18 & 935.70 \\
\hline Temperature & $89(2) \mathrm{K}$ & $89(2) \mathrm{K}$ \\
\hline Wavelength & $0.71073 \AA$ & $0.71073 \AA$ \\
\hline Crystal system & Triclinic & Monoclinic \\
\hline Space group & $P-1$ & $P 2_{1} / n$ \\
\hline \multirow[t]{6}{*}{ Unit cell dimensions } & $a=8.9076(5) \AA$ & $a=12.2159(18) \AA$ \\
\hline & $\alpha=103.436(3)^{\circ}$ & $\alpha=90^{\circ}$ \\
\hline & $b=12.2384(7) \AA$ & $b=9.5253(13)$ \\
\hline & $\beta=102.099(3)^{\circ}$ & $\beta=92.623(8)^{\circ}$ \\
\hline & $c=13.5807(8) \AA$ & $c=27.093(4) \AA$ \\
\hline & $\gamma=105.233(3)^{\circ}$ & $\gamma=90^{\circ}$ \\
\hline Volume & $1330.35(13) \AA^{3}$ & $3149.2(8) \AA^{3}$ \\
\hline Z & 1 & 4 \\
\hline Density (calculated) & $1.548 \mathrm{Mg} / \mathrm{m}^{3}$ & $1.974 \mathrm{Mg} / \mathrm{m}^{3}$ \\
\hline Absorption coefficient & $0.875 \mathrm{~mm}^{-1}$ & $5.820 \mathrm{~mm}^{-1}$ \\
\hline Crystal size & $0.52 \times 0.06 \times 0.06 \mathrm{~mm}^{3}$ & $0.40 \times 0.10 \times 0.02 \mathrm{~mm}^{3}$ \\
\hline \multirow[t]{3}{*}{ Index ranges } & $-11<=h<=11$ & $-15<=h<=15$ \\
\hline & $-15<=k<=15$ & $-11<=k<=12$ \\
\hline & $-16<=l<=33$ & $-33<=l<=33$ \\
\hline $\begin{array}{l}\text { Theta range for data } \\
\text { collection }\end{array}$ & $1.81-26.42^{\circ}$ & $1.50-27.12^{\circ}$ \\
\hline Reflections collected & 34,790 & 44,071 \\
\hline Independent reflections & $5452[R($ int $)=0.0353]$ & $6419[R(\mathrm{int})=0.1314]$ \\
\hline Refinement method & $\begin{array}{l}\text { Full-matrix least-squares } \\
\text { on } F^{2}\end{array}$ & $\begin{array}{l}\text { Full-matrix least-squares } \\
\text { on } F^{2}\end{array}$ \\
\hline $\begin{array}{l}\text { Data/restraints/ } \\
\text { parameters }\end{array}$ & $5452 / 0 / 390$ & $6419 / 0 / 426$ \\
\hline Goodness-of-fit on $F^{2}$ & 1.038 & 1.150 \\
\hline $\begin{array}{l}\text { Final } R \text { indices } \\
\qquad[I>2 \operatorname{sigma}(I)]\end{array}$ & $R_{1}=0.0261, \mathrm{w} R_{2}=0.0635$ & $R_{1}=0.0604, \mathrm{w} R_{2}=0.1340$ \\
\hline$R$ indices (all data) & $R_{1}=0.0317, w R_{2}=0.0661$ & $R_{1}=0.1058, \mathrm{w} R_{2}=0.1587$ \\
\hline $\begin{array}{l}\text { Largest diff. peak and } \\
\text { hole }\end{array}$ & 0.322 and -0.359 e..$\AA^{-3}$ & 1.620 and -1.115 e. $\AA^{-3}$ \\
\hline
\end{tabular}


Table 3

Physical data for the Schiff base ligands $\mathbf{2 a - 2} \mathbf{k}$ and their corresponding $\mathrm{Cu}(\mathrm{II})$ complexes $\mathbf{3 a}-\mathbf{3 k}$.

\begin{tabular}{|c|c|c|c|c|c|c|c|c|c|c|}
\hline \multirow[t]{2}{*}{ Compound } & \multirow[t]{2}{*}{$\mathrm{Mw}(\mathrm{g} / \mathrm{mol})$} & \multirow[t]{2}{*}{$\mu_{\text {eff }}$ (B.M.) } & \multirow[t]{2}{*}{ Yield (\%) } & \multirow[t]{2}{*}{ Empirical formula } & \multicolumn{4}{|c|}{ Found (calc) (\%) } & \multirow[t]{2}{*}{ m.p. $\left({ }^{\circ} \mathrm{C}\right)$} & \multirow[t]{2}{*}{$\Lambda_{\mathrm{M}}\left(\mathrm{S} \mathrm{cm}^{2} / \mathrm{mol}\right)$} \\
\hline & & & & & C & $\mathrm{H}$ & $\mathrm{N}$ & $\mathrm{Cu}$ & & \\
\hline $2 a$ & 279.29 & - & 78 & $\mathrm{C}_{17} \mathrm{H}_{13} \mathrm{NO}_{3}$ & $73.34(73.13)$ & $4.77(4.66)$ & $5.05(5.01)$ & $10.3(10.0)$ & $178-180$ & - \\
\hline 3a & 1240.18 & $1.63\left(2.28^{*}\right)$ & 80 & $\mathrm{C}_{34} \mathrm{H}_{24} \mathrm{CuN}_{2} \mathrm{O}_{8}$ & $65.31(65.85)$ & $3.77(3.90)$ & $4.38(4.52)$ & & $230-232$ & 10.71 \\
\hline 2b & 295.3 & - & 89 & $\mathrm{C}_{17} \mathrm{H}_{13} \mathrm{NO}_{4}$ & $68.87(69.15)$ & $4.34(4.44)$ & $4.78(4.74)$ & $9.7(10.5)$ & $238-240$ & - \\
\hline 3b & 652.11 & 1.77 & 83 & $\mathrm{C}_{34} \mathrm{H}_{24} \mathrm{CuN}_{2} \mathrm{O}_{8}$ & $62.49(62.62)$ & $3.70(3.71)$ & $4.15(4.30)$ & & $300-304$ & 21.4 \\
\hline 2c & 295.3 & - & 60 & $\mathrm{C}_{17} \mathrm{H}_{13} \mathrm{NO}_{4}$ & 68.62 (69.17) & $4.40(4.44)$ & $4.67(4.74)$ & $8.35(8.6)$ & $219-220$ & - \\
\hline 3c & 652.09 & 1.81 & 76 & $\mathrm{C}_{34} \mathrm{H}_{24} \mathrm{CuN}_{2} \mathrm{O}_{8}$ & $59.25(59.26)$ & $3.63(3.93)$ & $3.52(3.64)$ & & $>320$ & 8.45 \\
\hline 2d & 309.18 & - & 92 & $\mathrm{C}_{18} \mathrm{H}_{15} \mathrm{NO}_{4}$ & $69.48(69.8)$ & $4.71(4.89)$ & $4.43(4.53)$ & $9.3(10.0)$ & 200-202 & - \\
\hline 3d & 680.16 & 1.97 & 70 & $\mathrm{C}_{36} \mathrm{H}_{28} \mathrm{CuN}_{2} \mathrm{O}_{8}$ & $63.26(63.57)$ & $4.14(4.15)$ & $3.81(4.12)$ & & $304-306$ & 3.68 \\
\hline $2 e$ & 323.36 & - & 77 & $\mathrm{C}_{19} \mathrm{H}_{17} \mathrm{NO}_{4}$ & $70.40(70.58)$ & $5.33(5.30)$ & $4.48(4.33)$ & $9.0(7.6)$ & $150-152$ & - \\
\hline $3 \mathbf{e}$ & 708.21 & - & 37 & $\mathrm{C}_{38} \mathrm{H}_{32} \mathrm{CuN}_{2} \mathrm{O}_{8}$ & $62.67(64.44)$ & $4.95(4.55)$ & $3.85(3.96)$ & & $232-238$ & - \\
\hline 2f & 309.32 & - & 86 & $\mathrm{C}_{18} \mathrm{H}_{15} \mathrm{NO}_{4}$ & $69.81(69.89)$ & $4.77(4.89)$ & $4.30(4.53)$ & $9.3(8.9)$ & $194-197$ & - \\
\hline $3 f$ & 680.16 & 1.98 & 86 & $\mathrm{C}_{36} \mathrm{H}_{28} \mathrm{CuN}_{2} \mathrm{O}_{8}$ & $62.99(60.19)$ & $4.15(4.29)$ & $3.72(3.51)$ & & $>320$ & 2.59 \\
\hline $2 \mathrm{~g}$ & 348.18 & - & 66 & $\mathrm{C}_{17} \mathrm{H}_{11} \mathrm{NO}_{3} \mathrm{Cl}_{2}$ & $58.37(58.64)$ & $3.17(3.18)$ & $3.52(4.02)$ & $8.4(8.5)$ & $260-262$ & - \\
\hline $3 g$ & 757.89 & 1.76 & 94 & $\mathrm{C}_{34} \mathrm{H}_{20} \mathrm{Cl}_{2} \mathrm{CuN}_{2} \mathrm{O}_{6}$ & $53.76(53.88)$ & $2.75(2.66)$ & $3.73(3.70)$ & & $>320$ & 14.9 \\
\hline $2 h$ & 437.08 & - & 96 & $\mathrm{C}_{17} \mathrm{H}_{11} \mathrm{NO}_{3} \mathrm{Br}_{2}$ & $46.82(46.71)$ & $2.55(2.54)$ & $3.01(3.20)$ & $6.8(6.5)$ & $270-273$ & - \\
\hline $3 h$ & 935.69 & 1.76 & 91 & $\mathrm{C}_{34} \mathrm{H}_{20} \mathrm{Br}_{2} \mathrm{CuN}_{2} \mathrm{O}_{6}$ & $43.44(43.64)$ & $2.27(2.15)$ & $2.98(2.99)$ & & $316-318$ & 15.32 \\
\hline $2 \mathbf{i}$ & 531.08 & - & 97 & $\mathrm{C}_{17} \mathrm{H}_{11} \mathrm{NO}_{3} \mathrm{I}_{2}$ & $38.37(38.45)$ & $2.04(2.09)$ & $2.64(2.64)$ & $5.67(4.9)$ & $274-276$ & - \\
\hline $3 \mathbf{i}$ & 1123.69 & 2.18 & 81 & $\mathrm{C}_{34} \mathrm{H}_{20} \mathrm{I}_{2} \mathrm{CuN}_{2} \mathrm{O}_{6}$ & $36.17(36.34)$ & $1.93(1.79)$ & $2.33(2.49)$ & & $304-306$ & 9.92 \\
\hline $2 \mathbf{j}$ & 324.29 & - & 81 & $\mathrm{C}_{17} \mathrm{H}_{12} \mathrm{~N}_{2} \mathrm{O}_{5}$ & $63.27(62.96)$ & $3.58(3.73)$ & $8.82(8.64)$ & $9.0(8.6)$ & $310-312$ & - \\
\hline $\mathbf{3 j}$ & 710.11 & 1.76 & 95 & $\mathrm{C}_{34} \mathrm{H}_{22} \mathrm{CuN}_{4} \mathrm{O}_{10}$ & $56.28(57.51)$ & $3.17(3.12)$ & $7.53(7.89)$ & & $>320$ & 7.19 \\
\hline 2k & 354.31 & - & 91 & $\mathrm{C}_{18} \mathrm{H}_{14} \mathrm{~N}_{2} \mathrm{O}_{6}$ & $59.28(61.02)$ & $3.91(3.98)$ & $7.67(7.91)$ & $7.1(7.3)$ & $292-294$ & - \\
\hline 3k & 770.16 & 1.73 & 94 & $\mathrm{C}_{36} \mathrm{H}_{26} \mathrm{CuN}_{4} \mathrm{O}_{12}$ & $55.20(56.14)$ & $3.59(3.40)$ & $7.12(7.27)$ & & $318-320$ & 21.1 \\
\hline
\end{tabular}

Value for $2 \mathrm{Cu}(\mathrm{II})$ atoms.

Table 4

Characteristic ${ }^{1} \mathrm{H}$ NMR signals (ppm), peak multiplicity and coupling constants $J(\mathrm{~Hz})$ for the Schiff base ligands recorded in $\mathrm{d}_{6}$-DMSO

\begin{tabular}{|c|c|c|c|c|c|c|c|}
\hline Schiff base ligand & $\mathrm{H}_{3}$ (vinyl) & $\mathrm{H}_{11}\left(\mathrm{CH}_{3}\right)$ & $\mathrm{H}_{13}(\mathrm{CH}=\mathrm{N})$ & $\mathrm{H}_{15}(\mathrm{OH})$ & $R_{1}$ & $R_{2}$ & $R_{3}$ \\
\hline 2a & $6.39, \mathrm{~s}$ & $2.44, \mathrm{~s}$ & $9.03, \mathrm{~s}$ & $12.63, \mathrm{~s}$ & $6.99, \mathrm{~d}, J=8.43$ & $7.47, \mathrm{t}, J=17.3$ & $7.01, \mathrm{t}, J=16.65$ \\
\hline 2b & $6.37, \mathrm{~s}$ & $2.45, \mathrm{~s}$ & $9.01, \mathrm{~s}$ & $12.69, \mathrm{~s}$ & $9.32, \mathrm{~s}(-\mathrm{OH})$ & $6.99, \mathrm{dd}, J=9.54$ & $6.82, \mathrm{t}, J=7.68$ \\
\hline 2c & $6.31, s$ & 2.27, s & $8.90, \mathrm{~s}$ & $13.13, \mathrm{~s}$ & $6.36, s$ & $10.42, \mathrm{~s}(-\mathrm{OH})$ & $6.44, \mathrm{~d}, J=10.42$ \\
\hline 2d & $6.34, \mathrm{~s}$ & $2.40, \mathrm{~s}$ & $9.01, \mathrm{~s}$ & $12.54, \mathrm{~s}$ & $3.89, \mathrm{~s}\left(-\mathrm{OCH}_{3}\right)$ & $7.16, \mathrm{dd}, J=7.39$ & $6.93, \mathrm{t}, J=15 . .75$ \\
\hline $2 e$ & $6.38, \mathrm{~s}$ & $2.45, \mathrm{~s}$ & $9.04, \mathrm{~s}$ & $12.81, \mathrm{~s}$ & $4.09, \mathrm{q}\left(-\mathrm{OCH}_{2}-\right) 1.36, \mathrm{t}\left(-\mathrm{CH}_{3}\right)$ & $7.15, \mathrm{dd}, J=8.05$ & $6.90, \mathrm{t}, J=15.72$ \\
\hline $2 f$ & $6.32, \mathrm{~s}$ & $2.44, \mathrm{~s}$ & $8.93, \mathrm{~s}$ & $13.13, \mathrm{~s}$ & $6.56, \mathrm{~s}$ & $3.83, \mathrm{~s}\left(-\mathrm{OCH}_{3}\right)$ & $6.60, \mathrm{~d}, J=2.37$ \\
\hline $2 \mathrm{~g}$ & $5.90, \mathrm{~s}$ & $1.73, \mathrm{~s}$ & 8.39, s & $8.10, s$ & $-\mathrm{Cl}$ & na* & $-\mathrm{Cl}$ \\
\hline $2 h$ & $5.88, \mathrm{~s}$ & $2.44, \mathrm{~s}$ & $9.06, \mathrm{~s}$ & $8.10, \mathrm{~s}$ & $-\mathrm{Br}$ & $\mathrm{na}^{*}$ & $-\mathrm{Br}$ \\
\hline $2 \mathbf{i}$ & $6.42, \mathrm{~s}$ & $2.50, \mathrm{~s}$ & $9.61, \mathrm{~s}$ & $9.88, \mathrm{~s}$ & $-\mathrm{I}$ & na $^{*}$ & $-I$ \\
\hline $2 \mathbf{j}$ & $5.90, \mathrm{~s}$ & $2.27, \mathrm{~s}$ & $8.72, \mathrm{~s}$ & $9.19, \mathrm{~s}$ & na* & na* & $-\mathrm{NO}_{2}$ \\
\hline $2 \mathbf{k}$ & $6.41, s$ & $2.25, \mathrm{~s}$ & $8.34, \mathrm{~s}$ & $9.22, \mathrm{~s}$ & $8.87, \mathrm{~s}\left(-\mathrm{OCH}_{3}\right)$ & na* & $-\mathrm{NO}_{2}$ \\
\hline
\end{tabular}

$\mathrm{s}$ - singlet, $\mathrm{d}$ - doublet, $\mathrm{t}$ - triplet, $\mathrm{dd}$ - double doublet, $\mathrm{q}$ - quatet.

na - not assigned as signals overlapped.

Table 5

Characteristic ${ }^{13} \mathrm{C}$ NMR signals ( $\mathrm{ppm}$ ) for the Schiff base ligands recorded in $\mathrm{d}_{6}$-DMSO.

\begin{tabular}{|c|c|c|c|c|c|c|c|c|c|c|}
\hline Schiff base ligand & C2 (lactone) & C3 (vinyl) & $\mathrm{C} 4$ & $\mathrm{C7}$ & C9 & $\mathrm{C} 10$ & C11 (methyl) & C13 (imine) & $\mathrm{C} 14$ & C15 (phenol) \\
\hline $2 a$ & 159.80 & 113.63 & 153.0 & 152.95 & 151.41 & 119.27 & 18.10 & 165.08 & 118.08 & 160.29 \\
\hline 2b & 159.82 & 113.63 & 153.88 & 152.96 & 151.94 & 118.09 & 18.12 & 165.62 & 119.38 & 149.36 \\
\hline $2 c$ & 159.89 & 108.11 & 153.01 & 153.97 & 151.51 & 117.54 & 18.11 & 164.23 & 112.03 & 163.19 \\
\hline 2d & 154.93 & 108.92 & 149.24 & 143.38 & na & 113.41 & 13.24 & 160.27 & 114.75 & 148.06 \\
\hline $2 e$ & 154.79 & 113.65 & 152.95 & 153.86 & 151.07 & 118.14 & 18.11 & 165.36 & 119.25 & 150.88 \\
\hline $2 f$ & 159.78 & 113.41 & 152.88 & 154.04 & 151.36 & 117.77 & 18.03 & 164.12 & 113.09 & 163.25 \\
\hline $2 g$ & 160.9 & 112.5 & 152.8 & na & 151.50 & na & 21.20 & 160.10 & 157.90 & na \\
\hline $2 h$ & na & 94.01 & na & na & na & na & 25.78 & 158.45 & na & na \\
\hline $2 \mathbf{i}$ & na & 94.01 & na & na & na & na & 25.78 & 160.10 & na & na \\
\hline $2 \mathbf{j}$ & 160.9 & 112.5 & 152.59 & 152.8 & na & na & 21.20 & 167.2 & na & na \\
\hline 2k & 158.95 & 152.8 & 158.79 & 153.8 & na & na & 17.36 & 162.36 & 156.2 & na \\
\hline
\end{tabular}

na - not assigned.

\subsection{Synthesis of $\mathrm{Cu}(\mathrm{II})$ complexes (3a-3k)}

The $\mathrm{Cu}(\mathrm{II})$ complexes were prepared by the following general method: $2.4 \mathrm{mmol}$ of the appropriate ligand $(\mathbf{2 a - 2 k})$ was dissolved in ethanol $(40 \mathrm{~mL})$ and a solution of copper(II) acetate $(0.22 \mathrm{~g}$, $1.2 \mathrm{mmol})$ in ethanol $(10 \mathrm{~mL})$ was added. The resulting mixture was heated under reflux for up to $4 \mathrm{~h}$. After cooling, the precipitated product was collected by filtration, washed with water and dried in air. 3a and $\mathbf{3 h}$ were recrystallised by vapour diffusion of ethanol into acetonitrile and dimethylformamide (DMF), respectively. Despite repeated attempts to recrystallise the other $\mathrm{Cu}(\mathrm{II})$ complexes good quality crystals of the remaining complexes were not obtained. 
Table 6

Selected IR data $\left(\mathrm{cm}^{-1}\right)$ for the Schiff base ligands $\mathbf{2 a - 2 k}$.

\begin{tabular}{lllll}
\hline Schiff base & $v(\mathrm{CH}=\mathrm{N})$ & $v(\mathrm{C}=\mathrm{O})$ & $v(\mathrm{C}-\mathrm{O})$ & $v(\mathrm{O}-\mathrm{H})$ \\
\hline $\mathbf{2 a}$ & 1619 & 1710 & 1270 & 3435 \\
$\mathbf{2 b}$ & 1606 & 1722 & 1237 & 3289 \\
$\mathbf{2 c}$ & 1599 & 1688 & 1239 & 3243 \\
$\mathbf{2 d}$ & 1598 & 1728 & 1251 & 3248 \\
$\mathbf{2 e}$ & 1599 & 1727 & 1246 & 3432 \\
$\mathbf{2 f}$ & 1610 & 1733 & 1250 & 3437 \\
$\mathbf{2 g}$ & 1596 & 1727 & 1269 & 3435 \\
$\mathbf{2 h}$ & 1591 & 1727 & 1224 & 3430 \\
$\mathbf{2 i}$ & 1580 & 1716 & 1325 & 3431 \\
$\mathbf{2 j}$ & 1602 & 1720 & 1277 & 3432 \\
$\mathbf{2 k}$ & 1599 & 1716 & 1268 & 3432 \\
\hline
\end{tabular}

\subsection{X-ray crystallography}

X-ray crystallographic studies were performed at the University of Otago, New Zealand on a Bruker Kappa Apex II diffractometer with a CCD area detector. All of the crystal structures were solved using SHELXS-97. All structures were refined against $\mathrm{F}^{2}$ using all data by full-matrix least-squares techniques with ShelX-86 and SHELXL-97 $[49,50]$. Details of the data collections, solutions and refinements for $\mathbf{3 a}$ and $\mathbf{3 h}$ are given in Table 2. CCDC numbers: 707548 and 707549 for 3a and 3h, respectively.

\subsection{Anti-Candida susceptibility testing}

The ligands, complexes and commercially available drugs, ketoconazole and Amphotericin B, were tested against a clinical isolate of the fungal strain, C. albicans (ATCC 10231). The anti-Candida activities were determined using a broth microdilution susceptibility protocol (NCCLS) [51]. The screening protocol included the following steps: Isolates were grown for $24 \mathrm{~h}$ on Sabouraud dextrose agar (SDA) plates at $37{ }^{\circ} \mathrm{C}$. Cell suspensions were prepared in sterile phosphate buffered saline (PBS) to a density equal to a 1.0 McFarland standard yielding a concentration of $1 \times 10^{6}$ cells $/ \mathrm{mL}$ and then further diluted $(1: 100)$ with minimal media. Ligands, complexes and the commercial drug were prepared as $1 \%$ solutions or suspensions where appropriate in DMSO. All compounds were tested at a range of concentrations of $20,10,5$ and $1 \mu \mathrm{g} / \mathrm{mL}$, and the plates were incubated for $24 \mathrm{~h}$ at $37^{\circ} \mathrm{C}$. Each compound was assessed in triplicate and three independent experiments were performed. As most of the synthesised complexes were only soluble in DMSO, the effect of the solvent on the growth of $C$. albicans was also studied.

\section{Results and discussion}

\subsection{Synthesis and characterisation of the Schiff base ligands (2a-2k)}

Condensation of the amino coumarin 1 with a number of substituted salicylaldehydes yielded a series of Schiff bases in good yield (Table 3 ). The products were obtained by refluxing ethanolic solutions of starting materials in the presence of a catalytic amount of acetic acid (Scheme 1). Physical data and empirical formulae are presented in Table 3 . All of the ligands had good solubility in a range of organic solvents.

The ${ }^{1} \mathrm{H}$ - and ${ }^{13} \mathrm{C}$ NMR spectra of the ligands were recorded in $\mathrm{d}_{6}$ DMSO and the data are reported in Tables 4 and 5. The most characteristic signal in the ${ }^{1} \mathrm{H}$ NMR spectrum of each Schiff base was due to the imine hydrogen singlet found in the range 8.8$9.2 \mathrm{ppm}$. The singlet for the phenolic proton of the ortho-hydroxy group was present in the range $10-13 \mathrm{ppm}$, the downfield shift resulting from the intramolecular hydrogen bonding to the imine nitrogen. If the Schiff base ligands contained other hydroxyl sub-<smiles>[R3]c1cc(C=O)c(O)c([R])c1[R]</smiles>

(1)<smiles>[R]c1cc(/C=N/c2ccc3c(c2)OC(=C)C=C3C)c(O)c([R])c1[R16]</smiles>

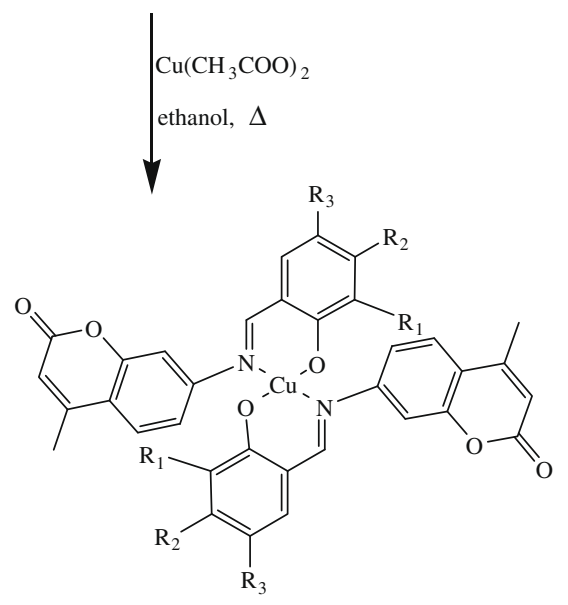

3a-3k

Scheme 1. Synthesis of coumarin-derived Schiff base ligands (2a-2k) and their corresponding $\mathrm{Cu}(\mathrm{II})$ complexes (3a-3k) (proposed structure of the complexes $\mathbf{3 b} \mathbf{b}-$ 3k).

stituents, then additional singlets appear in the range 9-11 ppm. Where possible, the ${ }^{13} \mathrm{C}$ NMR signals of the Schiff base ligands were assigned with the help of CHCHiFt cross peaks and DEPT experiments.

As expected the IR spectra of the Schiff base ligands exhibited a strong $v_{C=N}$ stretching vibration in the range $1619-1591 \mathrm{~cm}^{-1}$ (Table 6). The medium intensity bands in the region $1224-1277 \mathrm{~cm}^{-1}$ were assigned to the phenolic $v_{\mathrm{C}-\mathrm{O}}$ stretch. A broad band at ca. $3400 \mathrm{~cm}^{-1}$ was assigned to the $v_{\mathrm{OH}}$ stretch. The breadth of this band can be explained as the effect of intramolecular hydrogen bonding between the imine nitrogen and the hydrogen from the ortho-hydroxyl group [52,53].

The UV-vis spectra of the Schiff bases contained hypochromic absorption bands in the ultraviolet region of the spectra corresponding to the $\pi \rightarrow \pi^{*}$ transitions of the aromatic rings and of the conjugated system arising from the imine and coumarin moieties. Low intensity, broad bands, with absorption maxima at ca. $430 \mathrm{~nm}$, were assigned to forbidden $\mathrm{n} \rightarrow \pi^{*}$ transitions associated with the azomethine group [30,52,53].

\subsection{Synthesis and characterisation of the $\mathrm{Cu}(\mathrm{II})$ complexes (3a-3k)}

The appropriate ligand ( $\mathbf{2 a - 2 k )}$ was reacted with copper(II) acetate in a ratio of 2 ligand: $1 \mathrm{Cu}(\mathrm{II})$ in refluxing ethanol to give the corresponding copper(II) complexes (3a-3k) (Scheme 1). With 
the exception of $\mathbf{3 e}$ and $\mathbf{3 f}$ the microanalytical data corresponded to an empirical formulation of $1 \mathrm{Cu}^{2+}$ and 2 deprotonated Schiff base ligands (Table 3 ). Somewhat unsatisfactory results for several other complexes (3b, 3d, 3i, $\mathbf{3} \mathbf{j}$ and $\mathbf{3} \mathbf{k}$ ) may well be due to the poor solubility of these compounds generally which made recrystallisation of the complexes difficult. Despite repeated attempts to prepare a pure $\mathrm{Cu}(\mathrm{II})$ complex of $\mathbf{2 e}$, we were unable to do so and no antimicrobial screening of $\mathbf{3 e}$ was carried out. Most of the resulting complexes were soluble only in DMSO or DMF. The poor solubility of complexes (3d, $\mathbf{3 g}, \mathbf{3 j}$ and $\mathbf{3 k}$ ) prevented the recording of reliable UV-vis and conductivity measurements and it also meant that the antimicrobial screening of these complexes had to be carried out as suspensions.

\subsubsection{IR spectra of $\mathrm{Cu}(\mathrm{II})$ complexes}

In the IR spectra of almost all the complexes the $v_{\mathrm{CN}}$ stretching vibration associated with the imine functional group of the ligand was shifted to a lower wavelength compared to that in the corresponding free ligand, indicating that coordination to the $\mathrm{Cu}(\mathrm{II})$ ion occurs via the imine nitrogen (Table 7) [54,55]. The $v_{\mathrm{C}=0}$ stretching vibration of the carbonyl function in the lactone ring of the free ligands appeared as a strong sharp band in the range $1688-1733 \mathrm{~cm}^{-1}$. In the spectrum of most of the complexes, the position of this band remained largely unchanged, suggesting that the lactone carbonyl oxygen is not involved in coordination to the metal [56]. Upon complexation, the phenolic $v_{\mathrm{C}-\mathrm{O}}$ stretching vibration shifted to lower frequency, suggesting coordination of this oxygen atom. Several new bands present in the region 400$600 \mathrm{~cm}^{-1}$ in the spectra of the complexes were assigned to $v_{\mathrm{Cu}-\mathrm{N}}$ and $v_{\mathrm{Cu}-\mathrm{O}}$ stretching vibrations [52-55].

\subsubsection{UV-vis spectra of Schiff bases and their Cu(II) complexes}

UV-vis spectra of only two complexes could be reliably recorded over the full range due to solubility problems. Compared to the UV-vis spectra of the free ligands, significant changes in the wavelengths of absorption maxima were observed in those of the corresponding complexes (Table 8). All the spectra of the complexes contained broad bands in the UV region, with tailing into the visible region. The high energy bands at ca. $\lambda=340 \mathrm{~nm}$ were assigned to a ligand to metal change transfer (LMCT) transition, and the lower energy band in the region of ca. $\lambda=420 \mathrm{~nm}$ were assigned to a metal to ligand change transfer (MLCT) transition [52]. A low intensity absorption band in the visible region of the spectra of concentrated solutions of $\mathbf{3 b}$ and $\mathbf{3} \mathbf{c}$ correspond to a $\mathrm{d} \rightarrow \mathrm{d}^{*}$ transition, but solubility problems at high concentrations meant that the extinction coefficients at these wavelengths of other compounds are probably not accurate.

\subsubsection{Magnetic properties of $\mathrm{Cu}(\mathrm{II})$ complexes}

Values of magnetic susceptibility ( $\mu_{\text {eff }}$ ) for the $\mathrm{Cu}(\mathrm{II})$ complexes are given in Table 3. A mononuclear $\mathrm{Cu}(\mathrm{II})$ structure is assigned to

Table 7

Selected IR data $\left(\mathrm{cm}^{-1}\right)$ for the $\mathrm{Cu}(\mathrm{II})$ complexes $\mathbf{3 a}-\mathbf{3 k}$.

\begin{tabular}{llll}
\hline Complex & $v(\mathrm{CH}=\mathrm{N})$ & $v(\mathrm{C}=\mathrm{O})$ & $v(\mathrm{C}-\mathrm{O})$ \\
\hline $\mathbf{3 a}$ & 1607 & 1697 & 1266 \\
$\mathbf{3 b}$ & 1592 & 1719 & 1264 \\
$\mathbf{3 c}$ & 1590 & 1701 & 1233 \\
$\mathbf{3 d}$ & 1590 & 1725 & 1245 \\
$\mathbf{3 e}$ & 1586 & 1727 & 1219 \\
$\mathbf{3 f}$ & 1592 & 1726 & 1236 \\
$\mathbf{3 g}$ & 1598 & 1735 & 1263 \\
$\mathbf{3 h}$ & 1592 & 1734 & 1219 \\
$\mathbf{3 i}$ & 1588 & 1735 & 1313 \\
$\mathbf{3 j}$ & 1600 & 1719 & 1248 \\
$\mathbf{3 k}$ & 1595 & 1719 & 1257 \\
\hline
\end{tabular}

Table 8

Selected UV-vis data for the Schiff base ligands and their $\mathrm{Cu}(\mathrm{II})$ complexes recorded in DMSO.

\begin{tabular}{|c|c|c|c|}
\hline \multicolumn{2}{|l|}{ Schiff base } & \multicolumn{2}{|l|}{ Complex } \\
\hline$\lambda_{\max }(\mathrm{nm})$ & $\varepsilon\left(\mathrm{M}^{-1} \mathrm{~cm}^{-1}\right)$ & $\lambda_{\max }(\mathrm{nm})$ & $\varepsilon\left(\mathrm{M}^{-1} \mathrm{~cm}^{-1}\right)$ \\
\hline (2a) & & (3a) & \\
\hline 300 & 65,520 & 343 & 129,000 \\
\hline 353 & 37,650 & 422 & 51,400 \\
\hline$(2 \mathbf{b})$ & & $(\mathbf{3 b})$ & \\
\hline 290 & 63,000 & 339 & 135,600 \\
\hline \multirow[t]{2}{*}{354} & 36,030 & 421 & 44,900 \\
\hline & & 686 & 1090 \\
\hline$(2 c)$ & & $(3 c)$ & \\
\hline 280 & 96,930 & 351 & 59,650 \\
\hline \multirow[t]{2}{*}{354} & 112,300 & 436 & 67,870 \\
\hline & & 672 & 1900 \\
\hline
\end{tabular}

complexes $\mathbf{3 b}-\mathbf{3 k}$ as the $\mu_{\text {eff }}$ value for these complexes varied from 1.73 to 2.18 B.M., and is characteristic for this type of $\mathrm{Cu}(\mathrm{II}) \mathrm{com}$ plex [57-63]. The $\mu_{\text {eff }}$ value for complex 3a was 1.63 B.M. and is characteristic of a binuclear complex in which there is anti-ferromagnetic coupling between the $\mathrm{Cu}(\mathrm{II})$ centres $[59,60]$.

\subsubsection{Molar conductivity}

Determination of molar conductivities was carried out on those complexes that had good solubility in DMSO and the results obtained are given in Table 3 . The molar conductivity values determined for the complexes were in the range of $2.50-21.4 \mathrm{~S} \mathrm{~cm}^{2}$ / $\mathrm{mol}$, and were consistent with those recorded for other $\mathrm{Cu}(\mathrm{II}) \mathrm{Schiff}$ base complexes and would suggest their non-electrolytic character [64,65].

\subsubsection{Crystal structure analysis}

The structures of the copper(II) complexes $\mathbf{3 a}$ and $\mathbf{3 h}$ were determined by X-ray crystallography. The structure of complex 3a is shown in Fig. 2 and to our knowledge this is a first example of a binuclear $\mathrm{Cu}(\mathrm{II})$ complex of a coumarin Schiff base. Selected bond distances and angles are given in Table 9. The complex 3a is centrosymmetric and the coordination about each $\mathrm{Cu}(\mathrm{II})$ centre is completed with one imine nitrogen and one phenolic oxygen from a single Schiff base ligand, a bridging phenolic oxygen from an additional ligand which also provides a further imine nitrogen to coordinate singly to the metal centre. The final coordination site for each $\mathrm{Cu}(\mathrm{II})$ ion is filled by a phenolic oxygen atom from the second bridging Schiff base ligand. Therefore, each $\mathrm{Cu}(\mathrm{II})$ centre is bound to three Schiff base ligands with a different coordination mode to each ligand. Each $\mathrm{Cu}$ (II) ion is primarily in a coordination environment that may be considered as intermediate between distorted trigonal bipyramidal and a square pyramidal [66,67]. The copper ions are bridged by the two phenolic oxygen atoms with a short copper-copper distance of 2.61 (5) $⿱$ Á and a Cu-O6-Cu angle of $103.69(5)^{\circ}$. The rigid structure of the aromatic rings of orthosubstituted phenolic moieties usually favours square planar or square pyramidal coordination modes but the bulkiness of the ligand in this case causes a distortion of the trigonal bipyramidal structure. The known binuclear complex of bis(N-phenyl-5chloro-salicylideneaminato)copper(II), has a coordination geometry around the $\mathrm{Cu}(\mathrm{II})$ ion which is similar to that of $\mathbf{3 a}$ [68].

The crystal structure of $\mathbf{3 h}$ (Fig. 3) shows a mononuclear $\mathrm{Cu}(\mathrm{II})$ centre bound to two Schiff base ligands. The bond lengths and angles (Table 9) suggest a distorted square planar coordination environment for the metal [67]. Coordination of the $\mathrm{Cu}(\mathrm{II})$ centre to both ligands is via the imine nitrogen and phenolic oxygen atoms. Bond lengths between the $\mathrm{Cu}(\mathrm{II})$ centre and the donor atoms are consistent with previously reported compounds of similar structures $[54,67]$. There is no centre of symmetry in the molecule 


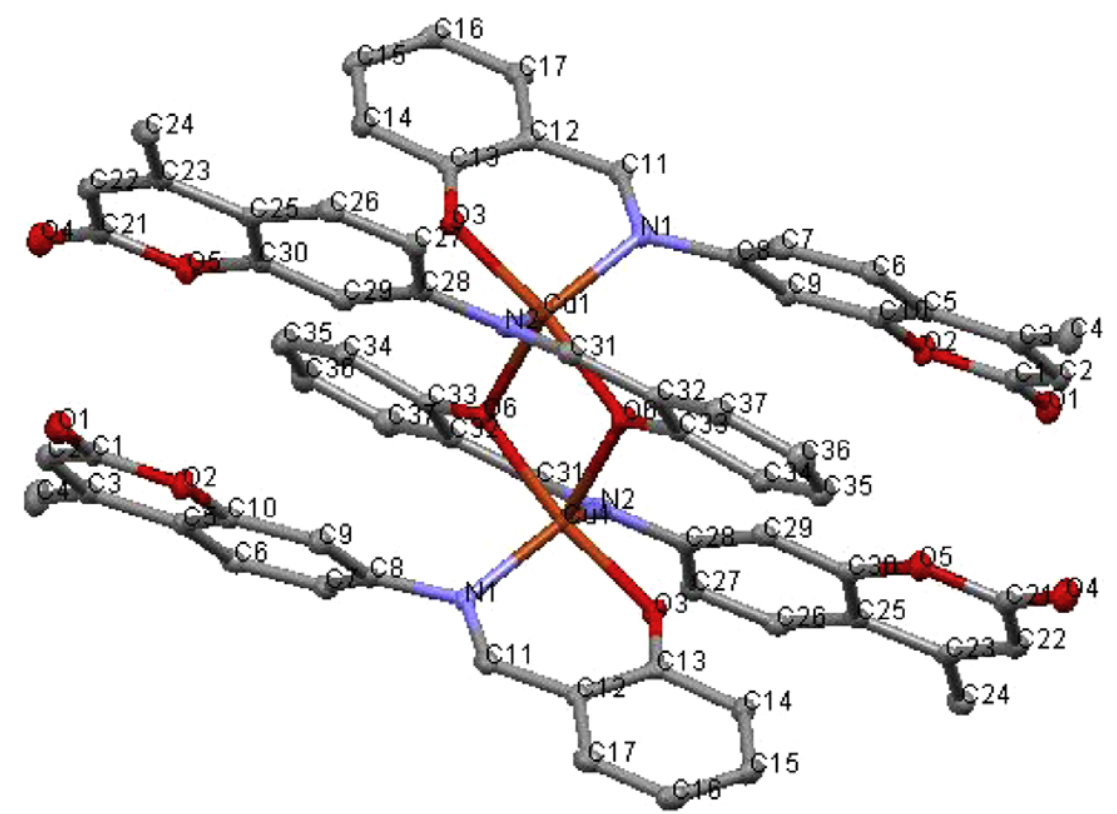

Fig. 2. Crystal structure of $3 a$.

Table 9

Selected bond lengths $(\AA)$ and angles $\left(^{\circ}\right)$ for $\mathbf{3 a}$ and $\mathbf{3 h}$

\begin{tabular}{lrlr}
\hline $\mathrm{Cu}(1)-\mathrm{O}(3)$ & $1.8820(11)$ & $\mathrm{Cu}(1)-\mathrm{O}(6)$ & $1.895(4)$ \\
$\mathrm{Cu}(1)-\mathrm{O}(6)$ & $1.9152(11)$ & $\mathrm{Cu}(1)-\mathrm{O}(3)$ & $1.897(5)$ \\
$\mathrm{Cu}(1)-\mathrm{N}(1)$ & $2.0379(14)$ & $\mathrm{Cu}(1)-\mathrm{N}(2)$ & $1.973(5)$ \\
$\mathrm{Cu}(1)-\mathrm{N}(2)$ & $2.0674(14)$ & $\mathrm{Cu}(1)-\mathrm{N}(1)$ & $2.001(5)$ \\
$\mathrm{Cu}(1)-\mathrm{O}(6) \# 1$ & $2.2785(12)$ & $\mathrm{N}(1)-\mathrm{C}(11)$ & $1.291(9)$ \\
& & $\mathrm{N}(1)-\mathrm{C}(8)$ & $1.441(8)$ \\
& & $\mathrm{O}(3)-\mathrm{C}(13)$ & $1.308(8)$ \\
$\mathrm{O}(3)-\mathrm{Cu}(1)-\mathrm{O}(6)$ & $169.13(5)$ & $\mathrm{O}(6)-\mathrm{Cu}(1)-\mathrm{O}(3)$ & $154.7(2)$ \\
$\mathrm{O}(3)-\mathrm{Cu}(1)-\mathrm{N}(1)$ & $91.02(5)$ & $\mathrm{O}(6)-\mathrm{Cu}(1)-\mathrm{N}(2)$ & $93.5(2)$ \\
$\mathrm{O}(6)-\mathrm{Cu}(1)-\mathrm{N}(1)$ & $93.98(5)$ & $\mathrm{O}(3)-\mathrm{Cu}(1)-\mathrm{N}(2)$ & $89.1(2)$ \\
$\mathrm{O}(3)-\mathrm{Cu}(1)-\mathrm{N}(2)$ & $94.04(5)$ & $\mathrm{O}(6)-\mathrm{Cu}(1)-\mathrm{N}(1)$ & $93.0(2)$ \\
$\mathrm{O}(6)-\mathrm{Cu}(1)-\mathrm{N}(2)$ & $89.52(5)$ & $\mathrm{O}(3)-\mathrm{Cu}(1)-\mathrm{N}(1)$ & $92.6(2)$ \\
$\mathrm{N}(1)-\mathrm{Cu}(1)-\mathrm{N}(2)$ & $133.42(5)$ & $\mathrm{N}(2)-\mathrm{Cu}(1)-\mathrm{N}(1)$ & $161.0(2)$ \\
$\mathrm{O}(3)-\mathrm{Cu}(1)-\mathrm{O}(6) \# 1$ & $92.91(5)$ & $\mathrm{C}(11)-\mathrm{N}(1)-\mathrm{Cu}(1)$ & $123.2(4)$ \\
$\mathrm{O}(6)-\mathrm{Cu}(1)-\mathrm{O}(6) \# 1$ & $76.37(5)$ & $\mathrm{C}(8)-\mathrm{N}(1)-\mathrm{Cu}(1)$ & $121.6(4)$ \\
$\mathrm{N}(1)-\mathrm{Cu}(1)-\mathrm{O}(6) \# 1$ & $108.19(5)$ & $\mathrm{C}(13)-\mathrm{O}(3)-\mathrm{Cu}(1)$ & $128.6(4)$ \\
$\mathrm{N}(2)-\mathrm{Cu}(1)-\mathrm{O}(6) \# 1$ & $117.72(5)$ & $\mathrm{C}(31)-\mathrm{N}(2)-\mathrm{Cu}(1)$ & $124.2(5)$ \\
& & $\mathrm{C}(28)-\mathrm{N}(2)-\mathrm{Cu}(1)$ & $120.8(4)$ \\
& & $\mathrm{C}(33)-\mathrm{O}(6)-\mathrm{Cu}(1)$ & $128.9(4)$ \\
\hline
\end{tabular}

which is reflected particularly in the bond length differences between copper and each of the nitrogen atoms of the two ligands coordinated to it; $1.973(5) \AA$ for $\mathrm{Cu}(1)-\mathrm{N}(2)$ and $2.001(5) \AA$ for $\mathrm{Cu}(1)-\mathrm{N}(1)$. The low symmetry in the molecule is also reflected in the relative $\mathrm{OCuN}$ bond angles; $\mathrm{O}(6)-\mathrm{Cu}(1)-\mathrm{N}(2)$ is $93.5(2)^{\circ}$ and $\mathrm{O}(3)-\mathrm{Cu}(1)-\mathrm{N}(1)$ is $92.6(2)^{\circ}$. The crystal packing diagram (Fig. 4) indicates aryl-aryl stacking interactions between the ring systems of adjacent molecules.

\subsubsection{Anti-Candida activities of Schiff Base ligands and $\mathrm{Cu}(\mathrm{II})$ complexes}

It has previously been reported that the amount of DMSO which is used to prepare samples for assessment of anti-Candida activity can affect the growth of the test strain used [69]. Therefore, before we tested the anti-Candida activity of the free ligands and their corresponding $\mathrm{Cu}(\mathrm{II})$ complexes we assessed the influence of the DMSO solvent on the growth of the Candida strain. The results indicated that the presence of $10 \%$ DMSO in the test mixture was highly toxic to the Candida cells, causing nearly $100 \%$ growth inhibition. 5\% DMSO affected nearly $80 \%$ growth inhibition of the
Candida cells, and was also not suitable for the further studies. Reducing DMSO concentration to $2 \%$ resulted in approximately $55 \%$ growth inhibition. Finally it was found that the presence of $1 \%$ of DMSO in the test mixture did not affect the growth of the fungus. Therefore, it was decided that for the available strain of C. albicans, the maximal final concentration of DMSO that can be used in the assay cannot be higher than $1 \%$.

The anti-Candida activity of the Schiff base ligands (2a-2k) and their $\mathrm{Cu}(\mathrm{II})$ complexes (3a-3k, except 3e) expressed as $\mathrm{MIC}_{50}$ values (the minimum concentration required to inhibit $50 \%$ of cells growth) is specified in Table 10. A number of the free ligands and complexes displayed anti-Candida activity comparable to those of the commercially available antifungal drugs, Amphotericin B and ketoconazole.

In our previous work on coumarin compounds, involving derivatised coumarin-3-carboxylic acids, 4-hydroxy-3-nitrocoumarin and coumarin dioxyacetic acid ligands, it was shown that none of the ligands had significant anti-Candida activity [23-25]. The results presented here show that a while a number of the coumarin Schiff base ligands have reasonable high $\mathrm{MIC}_{50}$ values, those of the halogenated and nitro derivatives are very low and are comparable to that of the commercially used antifungal agents, Amphotericin B and are indeed lower than that of the commercial drug, ketoconazole. In particular, the diiodo-substituted compound, $\mathbf{2 i}$ $\left(\mathrm{MIC}_{50}=1.2 \mu \mathrm{M}\right)$, was particularly active. These results also agree with the findings of Guo et al. who demonstrated that Schiff bases containing 2-hydroxy-5-nitro and 5-chloro-2-hydroxy-substituted aromatic rings have good antifungal activities [71]. Because of solubility problems a few of the $\mathrm{Cu}(\mathrm{II})$ complexes were tested as DMSO suspensions. $\mathrm{Cu}$ (II) acetate did not show anti-Candida activity at any of the test concentrations. Overall, complexes with good solubility in DMSO showed higher activity than those with poor solubility, but almost all complexes showed considerably increased activity over their corresponding metal-free Schiff base ligand. Interestingly, the complexes with dichloro and dibromo substituents on the ligand ( $\mathbf{3 g}$ and $\mathbf{3 h}$ ) exhibited high anti-Candida activity even as a DMSO suspension in the case of $\mathbf{3 g}$. Complex $\mathbf{3 i}$ was the most active of the series and maintained its significant activity (65\% growth inhibition) even at a concentration of $1 \mu \mathrm{g} /$ $\mathrm{mL}$. 


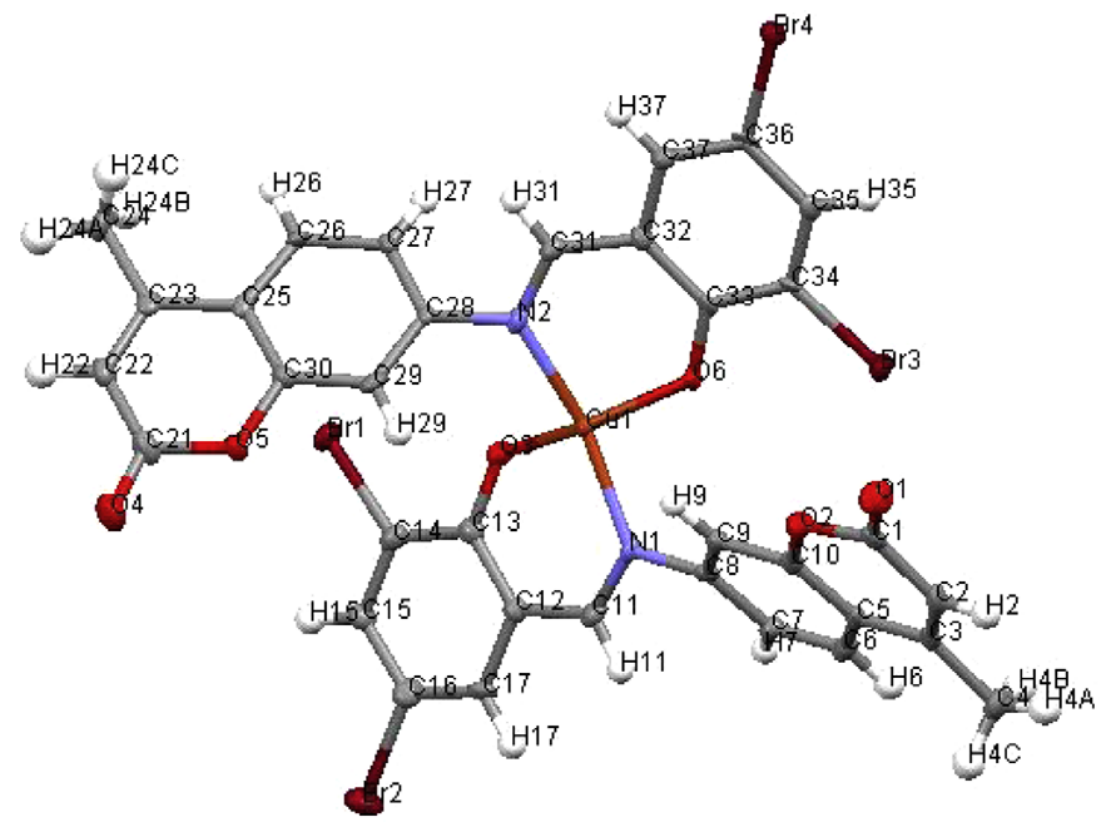

Fig. 3. Crystal structure of $\mathbf{3 h}$.

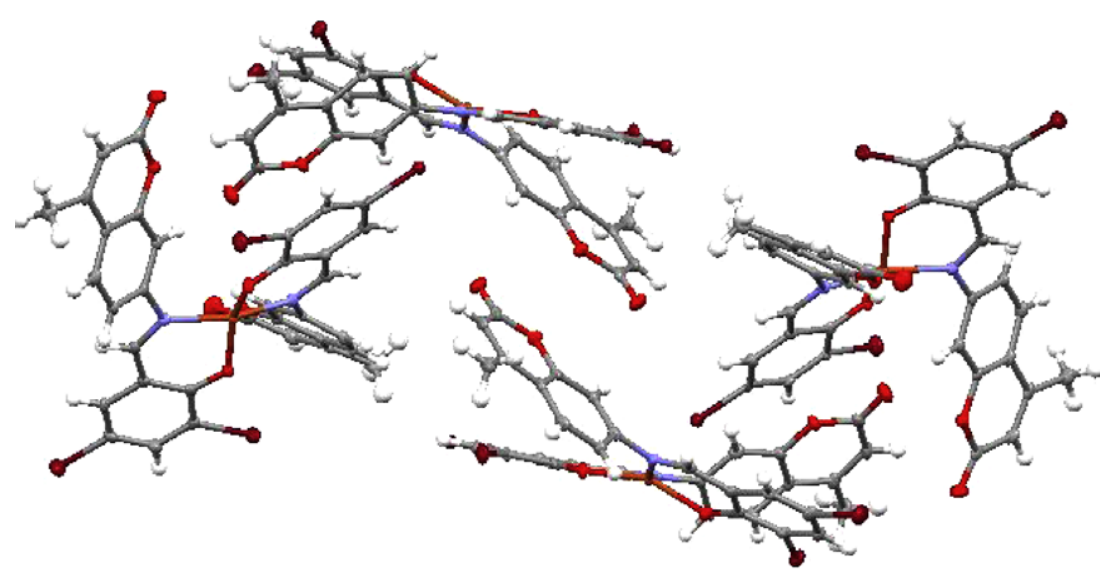

Fig. 4. Packing diagram for $3 \mathbf{h}$.

Table 10

Anti-Candida activity of Schiff base ligands and their $\mathrm{Cu}(\mathrm{II})$ complexes. See Fig. 1 for ligand structures and carbon and substituent numbering.

\begin{tabular}{|c|c|c|c|c|c|c|}
\hline Ligand & $\mathrm{MIC}_{50}(\mu \mathrm{M})$ & $\mathrm{Cu}(\mathrm{II})$ complex & $\mathrm{MIC}_{50}(\mu \mathrm{M})$ & $R_{1}$ & $R_{2}$ & $R_{3}$ \\
\hline $2 a$ & 92.3 & $3 a$ & 5.2 & $-\mathrm{H}$ & $-\mathrm{H}$ & $-\mathrm{H}$ \\
\hline 2b & 35.4 & $\mathbf{3 b}$ & 10.4 & $-\mathrm{OH}$ & $-\mathrm{H}$ & $-\mathrm{H}$ \\
\hline 2c & 89.2 & $3 c$ & 16.7 & $-\mathrm{H}$ & $-\mathrm{OH}$ & $-\mathrm{H}$ \\
\hline 2d & 62.0 & 3d & 8.2 & $-\mathrm{OCH}_{3}$ & $-\mathrm{H}$ & $-\mathrm{H}$ \\
\hline $2 e$ & 92.6 & $3 e$ & - & $-\mathrm{OCH}_{2} \mathrm{CH}_{3}$ & $-\mathrm{H}$ & $-\mathrm{H}$ \\
\hline 2f & 44.5 & $3 f$ & 14.5 & $-\mathrm{H}$ & $-\mathrm{OCH}_{3}$ & $-\mathrm{H}$ \\
\hline $2 \mathrm{~g}$ & 17.1 & $3 g$ & 3.6 & $-\mathrm{Cl}$ & $-\mathrm{H}$ & $-\mathrm{Cl}$ \\
\hline $2 h$ & 3.2 & $3 \mathbf{h}$ & 4.4 & $-\mathrm{Br}$ & $-\mathrm{H}$ & $-\mathrm{Br}$ \\
\hline $2 \mathbf{i}$ & 1.2 & $3 \mathbf{i}$ & 0.7 & $-I$ & $-\mathrm{H}$ & $-I$ \\
\hline $2 \mathbf{j}$ & 9.1 & $\mathbf{3 j}$ & 9.8 & $-\mathrm{H}$ & $-\mathrm{H}$ & $-\mathrm{NO}_{2}$ \\
\hline 2k & 95.4 & $3 k$ & 12.6 & $-\mathrm{OCH}_{3}$ & $-\mathrm{H}$ & $-\mathrm{NO}_{2}$ \\
\hline Amphotericin B & 0.7 & & & & & \\
\hline Ketoconazole $^{*}$ & 4.7 & & & & & \\
\hline
\end{tabular}

* Value recorded previously in our lab under the same conditions [70].

In general, it was found that Schiff base ligands with electronwithdrawing substituents such as $-\mathrm{Cl},-\mathrm{Br}$, or $-\mathrm{I}$, at the $R_{1}$ and $R_{3}$ positions of the salicylaldehyde moiety had greater anti-Candida activity than ligands with electron-donating substituents. Surprisingly, the complexation of these active ligands to $\mathrm{Cu}$ (II) ions resulted in only slight increases in the activity of the subsequent 
complexes. This is in stark contrast to the behaviour of the less active ligands (2a-2f, $\mathbf{2 k}$ ), whose $\mathrm{Cu}(\mathrm{II})$ complexes (3a-3d, 3f, 3k) in all cases were significantly more active against Candida. It is difficult to attribute these trends to changes in solubility alone. All of the ligands were freely soluble in a range of organic solvents whereas only some of the metal complexes were soluble in DMSO or DMF. Some of the most active complexes, i.e. $\mathbf{3 d}, \mathbf{3 g}$ and $\mathbf{3 j}$ were tested as suspensions and their $\mathrm{MIC}_{50}$ values were still lower than those of their corresponding free ligands. Previous work by Nair et al. reported a series of $\mathrm{Mn}$ (II) and $\mathrm{Cu}(\mathrm{II})$ complexes which exhibited activities lower than the activities of their corresponding free ligands when tested using separately 1,4-dioxane and DMF as solvent [72].

This present study has identified a series of coumarin-derived Schiff bases and their $\mathrm{Cu}(\mathrm{II})$ complexes who have displayed good antifungal activity against a clinical strain of $C$. albicans. We have also reported the first crystal structures of this type of metal complex.

\section{Acknowledgements}

This research was supported by the Technological Sector Research Programme, Strand 1, under the European Social Fund. DK would also like to thank the EMBARK fellowship for additional funding. The research was carried out by the Centre for Pharmaceutical Research and Development (CPRD) jointly located at Institutes of Technology, Tallaght and Dublin, and the NUI, Maynooth, Co. Kildare, Ireland.

\section{References}

[1] W.R. Jarvis, Clin. Infect. Dis. 20 (1995) 1526-1530.

[2] D. Warnock, J. Antimicrob. Chemother. 41 (1998) 95-105.

[3] R. Rogers, Int. J. Antimicrob. Agents 27 (2006) 7-11.

[4] G. Chamilos, D.P. Kontoyiannis, Drug Resist. Updat. 8 (2005) 344-358.

[5] E. Francois, A.M. Aerts, B.P. Cammue, K. Thevissen, Curr. Drug Targets 6 (2005) 895-907.

[6] B.H. Segal, J. Kwon-Chung, T.J. Walsh, B.S. Klein, M. Battiwalla, N.G. Almyroudis, S.M. Holland, L. Romani, Clin. Infect. Dis. 42 (2006) 507-515.

[7] M.B. Edmond, S.E. Wallace, D.K. McClish, M.A. Pfaller, R.N. Jones, R.P. Wenzel, Clin. Infect. Dis. 29 (1999) 239-244.

[8] R.A. Calderone, Candida and Candidiasis, ASM press, Washington, 2002.

[9] R.A. Akins, Med. Mycol. 43 (2005) 285-318.

[10] D. Sanglard, Curr. Opin. Microbiol. 5 (2002) 379-385

[11] D.P. Kontoyiannis, R.E. Lewis, Lancet 359 (2002) 1135-1144.

[12] M.A. Ghannoum, L.B. Rice, Clin. Microbiol. Rev. 12 (1999) 501-517.

[13] T. Ojala, S. Remes, P. Haansuu, H. Vuorela, R. Hiltunen, K. Haahtela, P. Vuorela, J. Ethnopharmacol. 73 (2000) 299-305.

[14] C. Kofinas, I. Chinou, A. Loukis, C. Harvala, M. Maillard, K. Hostettmann, Phytochemistry 48 (1998) 637-641.

[15] F. Cottiglia, G. Loy, D. Garan, C. Floris, M. Casu, R. Pompei, L. Bonsignore, Phytomedicine 8 (2001) 302-305.

[16] Y. Tada, Y. Shikishima, Y. Takaishi, H. Shibata, T. Higuti, G. Honda, M. Ito, Y. Takeda, O.K. Kodzhimatov, O. Ashurmetov, Y. Ohmoto, Phytochemistry 59 (2002) 649-654.

[17] R. Reyes-Chilpa, E. Estrada-Muniz, T.R. Apan, B. Amekraz, A. Aumelas, C.K. Jankowski, M. Vazquez-Torres, Life Sci. 75 (2004) 1635-1647.

[18] F.M. Al-Barwani, E.A. Eltayeb, Biochem. Syst. Ecol. 32 (2004) 1097-1108.

[19] K. Yasunaka, F. Abe, A. Nagayama, H. Okabe, L. Lozada-Perez, E. LopezVillafranco, E. Muniz, A. Aguilar, R. Reyes-Chilpa, J. Ethnopharmacol. 96 (2005) 293-299.

[20] A.C. Stein, S. Alvarez, C. Avancini, S. Zacchino, G. von Poser, J. Ethnopharmacol. 107 (2006) 95-98.

[21] M. Kawase, N. Motohasi, H. Sagakami, T. Kanamoto, H. Nakashima, L. Fereczy, K. Walfard, C. Miskolci, J. Molnar, Int. J. Antimicrob. Agents 18 (2001) 161-165.

[22] F. Borges, F. Roleira, M. Milhazes, L. Santana, E. Uriate, Curr. Med. Chem. 12 (2005) 887-916 (and references therein).

[23] B.S. Creaven, D.A. Egan, K. Kavanagh, M. McCann, M. Mahon, A. Noble, B. Thati, M. Walsh, Polyhedron 24 (2005) 949-957.

[24] B.S. Creaven, D.A. Egan, K. Kavanagh, M. McCann, M. Mahon, A. Noble, B. Thati, M. Walsh, Inorg. Chim. Acta 359 (2006) 3976-3984.

[25] B.S. Creaven, D.A. Egan, D. Karcz, K. Kavanagh, M. McCann, M. Mahon, A. Noble, B. Thati, M. Walsh, J. Inorg. Biochem. 101 (2007) 1108-1119.
[26] M.S. Karthikeyan, D.J. Prasad, B. Poojary, K.S. Bhat, B.S. Holla, N.S. Kumari, Bioorg. Med. Chem. 14 (2006) 7482-7489.

[27] S.U. Rehman, Z.H. Chohan, F. Gulnaz, C.T. Supuran, J. Enzyme Inhib. Med. Chem. 20 (2005) 333-340.

[28] A.C. Hiremath, M.A. Pujar, A.S.R. Murthy, Indian J. Chem. Section A 14 (1976) 908-909.

[29] N. Raman, S. Johnson Raja, A. Sakthivel, J. Coord. Chem. 62 (2009) 691709.

[30] O.D. Kachkovski, O.I. Tolmachev, L.O. Kobryn, E.E. Bila, M.I. Ganushchak, Dyes Pigments 63 (2004) 203-211.

[31] H. Turki, S. Abid, R. El Gharbi, S. Fery-Forgues, Comptes Rendus Chimie 9 (2006) 1252-1259.

[32] C.A. Kontogiorgis, D. Jhadjipavlou-Litina, Bioorg. Med. Chem. Lett. 14 (2004) 611-614.

[33] Z.M. Nofal, M.I. El-Zahar, S.S. Abd El-Karim, Molecules 5 (2000) 99-113.

[34] C.A. Kontogiorgis, K. Savvoglou, D.J. Hadjipavlou-Litina, J. Enzyme Inhib. Med. Chem. 21 (2006) 21-29.

[35] G. Kokotos, C. Tzougraki, J. Heterocycl. Chem. 23 (1986) 87-92.

[36] D.J. Hodgson, Prog. Inorg. Chem. 19 (1975) 173-241.

[37] M. Melnik, Coord. Chem. Rev. 42 (1982) 259-293.

[38] M. Kato, Y. Muto, Coord. Chem. Rev. 92 (1988) 45-83.

[39] J.E. Weder, C.T. Dillon, T.W. Hambley, B.J. Kennedy, P.A. Lay, J.R. Biffin, H.L. Regtop, N.M. Davies, Coord. Chem. Rev. 232 (2002) 95-126.

[40] S. Belaid, A. Landreau, S. Djebbar, O. Benali-Baitich, G. Bouet, J. Bouchara, J. Inorg. Biochem. 102 (2008) 63-69.

[41] M.P. Sathisha, U.N. Shetti, V.K. Revankar, K.S.R. Pai, Eur. J. Med. Chem. 43 (2008) 2338-2346.

[42] K.B. Gudasi, M.S. Patil, R.S. Vadavi, Eur. J. Med. Chem. 4 (2008) 2436-2441.

[43] V. Ambike, S. Adsule, F. Ahmed, Z. Wang, Z. Afrasiabi, E. Sinn, F. Sarkar, S. Padhye, J. Inorg. Biochem. 101 (2007) 1517-1524.

[44] L.T. Yıldırım, R. Kurtaran, H. NamLi, A.D. Azaz, O. Atakol, Polyhedron 26 (2007) 4187-4194.

[45] X. Zhong, H. Wei, W. Liu, D. Wang, X. Wang, Bioorg. Med. Chem. Lett. 17 (2007) $3774-3777$.

[46] J. Lv, T.G. Liu, S. Cai, X. Wang, L. Liu, Y. Wang, J. Inorg. Biochem. 100 (2006) $1888-1896$.

[47] G.B. Bagihalli, P.G. Avaji, S.A. Patil, P.S. Badami, Eur. J. Med. Chem. 43 (2008) 2639-2649.

[48] D.S. Bose, A.P. Rudradas, M.H. Babu, Tetrahedron Lett. 43 (2002) 9195-9197.

[49] G.M. Sheldrick, ShelX-86, Program for the Solution of Crystal Structures, University of Göttingen, Germany, 1986.

[50] G.M. Sheldrick, ShelX-97, Program for the Crystal Structure Refinement, University of Göttingen, Germany, 1997.

[51] NCCL (National Committee for Clinical Laboratory) Publication, Villanova, PA, M27-P, 1979.

[52] A. Golcu, M. Tumer, H. Demirelli, R.A. Wheatley, Inorg. Chim. Acta 358 (2005) $1785-1797$

[53] S.M. Ben-Saber, A.A. Maihub, S.S. Hudere, M.M. El-Ajaily, Microchem. J. 81 (2005) 191-194.

[54] A.L. Iglesias, G. Aguirre, R. Somanathan, M. Parra-Hake, Polyhedron 23 (2004) 3051-3062.

[55] H.S. Abbo, S.J.J. Titinchi, R. Prasad, S. Chand, J. Mol. Catal., A Chem. 225 (2005) 225-232.

[56] A. Karaliota, O. Kretsi, C. Tzougraki, J. Inorg. Biochem. 84 (2001) 33-37.

[57] R.N. Patel, N. Singh, K.K. Shukla, U.K. Chauhan, S. Chakraborty, J. NiclosGutierrez, A. Castineiras, J. Inorg. Biochem. 98 (2004) 231-237.

[58] K.S. Bharathi, A.K. Rahiman, K. Rajesh, S. Sreedaran, P.G. Aravindan, D. Velmurugan, V. Narayanan, Polyhedron 25 (2006) 2859-2868.

[59] R.C. Santana, J.F. Carvalho, I. Vencato, H.B. Napolitano, A.J. Bortoluzzi, G.E. Barberis, R.E. Rapp, M.C.G. Passeggi, R. Calvo, Polyhedron 26 (2007) 50015008.

[60] A.A. Soliman, G.G. Mohamed, Thermochim. Acta 421 (2004) 151-159.

[61] H. Saravani, A.R. Rezvani, G. Mansouri, A.R.S. Rad, H.R. Khavasi, H. Hadadzadeh, Inorg. Chim. Acta 360 (2007) 2829-2834.

[62] M. Tuncel, A. Ozbulbul, S. Serın, React. Funct. Polym. 68 (2008) 292-306.

[63] S. Chandra, S. Raizada, M. Tyagi, A. Gautam, Bioinorg. Chem. App. 11 (2007) Article ID 51483)

[64] E. Tas, A. Kilic, N. Konak, I. Yilmaz, Polyhedron 27 (2008) 1024-1032.

[65] S. AbouEl-Enein, F.A. El-Saied, S.M. Emam, M.A. Ell-Salamony, Spectrochim. Acta Part A 71 (2008) 421-429.

[66] A. Valent, M. Melnik, D. Hudecova, B. Dudova, R. Kivekas, M.R. Sundberg, Inorg. Chim. Acta 340 (2002) 15-20.

[67] P.A. Vigato, S. Tamburini, Coord. Chem. Rev. 248 (2004) 1717-2128.

[68] M.A. Randhava, Jpn. J. Med. Mycol. 47 (2006) 313-318.

[69] A. Takeuchi, H. Kuma, S. Yamada, Synth. React. Inorg. Met-org. Chem. 24 (1994) 171-183.

[70] R. Curran, J. Lenehan, M. McCann, K. Kavanagh, M. Devereux, D.A. Egan, G. Clifford, K. Keane, B.S. Creaven, V. McKee, Inorg. Chem. Commun. 10 (2007) 1149-1153.

[71] Z. Guo, R. Chen, R. Xing, S. Liu, H. Yu, P. Wang, C. Lia, P. Li, Carbohyd. Res. 341 (2006) 351-354.

[72] R. Nair, A. Shah, S. Baluja, S. Chanda, J. Serb. Chem. Soc. 71 (2006) 733-744. 